\title{
Studi Eksperimental dan Numerik Pengaruh Diameter dan Jumlah Lubang Perforasi Terhadap Kekuatan Tubing Liner Pada Unit Sand Control
}

\author{
A. Akhmadiansyah* dan I. M. Miasa \\ Departemen Teknik Mesin dan Industri, Fakultas Teknik, Universitas Gadjah Mada. \\ JI. Grafika No.2, Kompleks UGM, Yogyakarta 55281, Indonesia, \\ Telp. (0274) 521673 \\ *E-mail: gus.tom56@gmail.com
}

\begin{abstract}
Abstrak
Penambahan lubang perforasi pada tubing liner dengan variasi ukuran diameter dan jumlah lubang menjadikan rasio area perforasi meningkat. Dengan rasio area perforasi meningkat tentunya secara profit dapat menambah hasil produksi, namun juga berpotensi dapat menurunkan kekuatan material karena hilangnya sejumlah massa material. Penelitian ini bertujuan untuk mengetahui pengaruhnya terhadap nilai tegangan $(\sigma)$ dan konsentrasi $(K t)$ serta variasi perforasi yang memiliki nilai kekuatan sesuai standar. Penelitian berupa studi eksperimental dan numerik untuk menghasilkan model tubing liner berbahan material dan komponen buatan dalam negeri dengan memanfaatkan raw material hasil sumber daya alam Indonesia. Pengujian eksperimental dengan menggunakan material pipa tahan karat stainless steel 304 melalui metode uji tarik (tensile test) dan uji tekan (compressive test). Pengujian ini untuk mendapatkan nilai tegangan $(\sigma)$ dan regangan $(\varepsilon)$ material uji. Secara paralel, simulasi analisis elemen hingga juga dilakukan guna memperoleh data output yang kemudian divalidasi dengan hasil pengujian. Hasil penelitian menunjukkan material pipa tubing stainless steel 304 pada pengujian memiliki nilai tegangan luluh sebesar 364,3 $\mathrm{MPa}$, tegangan tarik maksimum sebesar 597,45 $\mathrm{MPa}$, dan tegangan tekan maksimum sebesar 701,83 MPa, dengan demikian material tubing telah memenuhi standar AISI 304 ASTM A240. Nilai faktor konsentrasi tegangan (Kt) meningkat dari 1,12 hingga 2,39 dan menyebabkan nilai tegangan $(\sigma)$ pada material semakin berkurang. Faktor konsentrasi tegangan $(K t)$ yang terjadi dapat menurunkan kekuatan struktur material. Penambahan lubang perforasi pada eksperimen uji tarik menurunkan nilai tegangan sebesar 4,15\% dan pada uji tekan sebesar $30,6 \%$. Kombinasi jumlah dan diameter perforasi yang terbaik pada penelitian adalah pada spesimen berdiameter lubang $10 \mathrm{~mm}$ karena memberikan nilai tegangan maksimum diatas nilai standar ASTM A240.
\end{abstract}

Kata kunci : Tubing liner, Eksperimental, Numerik, Konsentrasi tegangan.

\begin{abstract}
The addition of perforation holes in the tubing liner with variations in diameter and number of holes increases the perforation area ratio. By increasing the perforation area ratio, of course it can profitably increase the yield, but also has the potential to reduce the strength of the material due to the loss of a certain amount of material mass. This study aims to determine the effect on the value of stress $(\sigma)$ and concentration $(K t)$ as well as the variation of perforations which still
\end{abstract}


have a standard strength value. The research is in the form of experimental and numerical studies to produce a tubing liner model made from domestically made materials and components by utilizing raw materials from Indonesia's natural resources. Experimental testing using stainless steel 304 pipe material through the tensile and compressive test methods. This test is to obtain the value of stress $(\sigma)$ and strain $(\varepsilon)$ of the test material. In parallel, finite element analysis simulations are also carried out in order to obtain output data which is then validated with test results. The results showed that the 304 stainless steel tubing pipe material on the test had a yield stress value of $364.3 \mathrm{MPa}$, a maximum tensile stress of $597.45 \mathrm{MPa}$, and a maximum compressive stress of $701.83 \mathrm{MPa}$, thus the tubing material had met the AISI 304 ASTM standard A240. The value of the stress concentration factor $(K t)$ increases from 1.12 to 2.39 and causes the stress value $(\sigma)$ in the material to decrease. The stress concentration factor that occurs can reduce the strength of the material structure. The addition of perforation holes in the tensile test experiment decreased the stress value by $4.15 \%$ and in the compressive test by $30.6 \%$. The best combination of number and diameter of perforations in the test is a specimen with a hole diameter of $10 \mathrm{~mm}$ because it provides a maximum stress value above the ASTM A240 standard value.

Keywords : Tubing liner, Experimental, Numerical, Stress concentration.

\section{PENDAHULUAN}

Berdasarkan data pekerjaan ulang sumur (workover) tahun 2017 di salah satu wilayah eksplorasi minyak bumi di Provinsi Riau, ditemukan sekitar 21\% dari semua jumlah workover berkaitan dengan macetnya pompa, abrasi pompa dan plugging perpipaan akibat debris dan pasir. Penyebab utama timbulnya permasalahan tersebut berhubungan dengan masalah produksi pasir atau kepasiran. Permasalahan ini terjadi akibat terbawanya pasir dari lapisan formasi reservoir minyak bumi ke dalam saluran masuk pompa plunger yang ada di dalam sistem pompa angguk. Seiring waktu pasir formasi tersebut sebagian terakumulasi dan menumpuk di dalam barrel pompa dan sebagian lainnya terbawa aliran menuju pipa saluran produksi. Tumpukan pasir di dalam barrel plunger pompa tersebut menyebabkan pompa mengalami keausan berlebih atau bahkan kemacetan.

Metode sand control pada sumur produksi migas di Indonesia merupakan upaya mitigasi permasalahan produksi pasir. Salah satu metode sand control yang diaplikasikan adalah dengan menggunakan sand screen yang ditempatkan di depan perforasi untuk mencegah dan menyaring pasir dari lubang perforasi. Screen tersebut dipasang pada struktur penopang yaitu tubing liner yang juga berfungsi sebagai media filtrasi aliran hidrokarbon. Saat ini ketersediaan perangkat tubing liner, sand screen dan metal screen masih mengandalkan perangkat impor, sehingga menyebabkan adanya waktu tunggu yang relatif lebih lama. Hal ini menjadi kendala dalam proses perawatan sumur, khususnya dalam kasus-kasus yang membutuhkan penanganan segera. Inilah yang menjadi dasar pertimbangan tema penelitian, mengingat Indonesia memiliki sumber daya penghasil raw material yang menjadi bahan baku unit tubing liner. Fokus penelitian pada pengujian beberapa sampel tubing liner yang menggunakan pipa stainless steel 304 yang telah diperforasi. Penelitian ini berupa studi numerik yang divalidasi secara eksperimental meliputi tahapan uji tarik dan tekan pada material dan analisis elemen hingga dengan simulasi perangkat lunak.

Produksi pasir formasi ini adalah masalah yang sangat menantang hingga berakhirnya masa produksi reservoir dan sumur. Produksi pasir juga dapat membatasi laju alir produksi, sehingga menyebabkan kerugian ekonomis. Setiap kali terdapat kekhawatiran tentang produksi 
pasir di sumur yang sedang dikembangkan, manajemen dan sand control adalah tindakan utama yang harus diambil (Mahmud dkk., 2020). Perbandingan indeks kinerja secara individu dan komprehensif pada mechanical screen dengan tipe yang berbeda, menjadi sangat penting dalam evaluasi dan optimasi reservoir migas tertentu, serta akan menentukan efek akhir dari penanganan kepasiran dan umur pakai mechanical screen (Dong dkk., 2017). Teknik sand control yang paling umum untuk memaksimalkan produksi hidrokarbon adalah dengan memasang peralatan yang mencegah pasir formasi memasuki sumur. Sebagai barrier mekanis, sand screen menahan benda solid agar tidak mengalir bersama fluida reservoir. Bagaimanapun, partikel pasir bulat tidak akan mengalir terus menerus melalui lubang tubing dengan lebar diameter partikel yang sama, saat mengalir dalam konsentrasi yang sesuai (Penberthy dkk., 1992).

Pengembangan baru perangkat sand control canggih berbasis material keramik berhasil diperkenalkan dan difungsikan secara penuh di sumur GA-016 lapangan minyak Gaiselberg. Screen menunjukkan kinerja yang sangat baik dalam hal stabilitas produksi pada tingkat yang diharapkan, dimana kondisi lubang perforasi di sekitar screen stabil meskipun reservoir unconsolidated. Tidak ditemukan adanya penyumbatan serta tidak ada erosi yang terjadi seperti yang diharapkan. Instalasi tersebut terbukti sederhana dan hemat biaya. Dengan pemasangan sand screen keramik di GA-016 terjadi peningkatan yang signifikan dalam kinerja produksi dan umur panjang peralatan produksi telah tercapai (Wildhack dkk., 2012).

Kerusakan pipa casing yang tidak normal, terutama pada pipa berlubang merupakan masalah serius dalam proses eksplorasi dan pengembangan ladang minyak (Wang dkk., 1994). Penelitian sebelumnya menunjukkan bahwa kekuatan pipa casing dapat berkurang karena disebabkan oleh adanya perforasi. Pipa casing berlubang dengan beberapa lubang bundar pada permukaan silinder memiliki retak mikro di tepi lubang. Eksperimen diperlukan untuk mengukur konsentrasi tegangan dari pipa casing tersebut (Dou dkk., 2019). Axially Perforated Tube (APT) berperforma lebih baik dari Diagonal Perforated Tube (DPT) pada kompresi aksial. Beberapa parameter yang mempengaruhi perilaku kompresi aksial dari GFRP diantaranya diameter lubang, diameter tabung/tube, pola perforasi dan jarak lubang melintang. Rasio deformasi pada GFRP tanpa lubang bernilai 1, sementara pada APT bernilai 0,78 dan pada DPT bernilai 0,66 (Wang dkk., 2014). Pada screen/slotted liner di sumur geotermal harus memiliki struktur yang stabil dengan kondisi pembebanan yang terinduksi secara termal. Tujuannya untuk menjaga lubang sumur tetap stabil dan mencegah masuknya serpihan. Desain screen/slotted liner dengan metode elemen hingga akan memastikan bahwa liner memberikan hasil dengan area aliran maksimal dan reduksi kekuatan yang minimum dibandingkan dengan liner utuh (Yang dkk., 2018). Lubang pada struktur menjadi permasalahan serius karena dapat memicu lonjakan konsentrasi tegangan yang mengakibatkan retak pada struktur. Untuk memprediksi faktor konsentrasi tegangan pada pelat isotropik berlubang dengan pin-loaded menggunakan metode numerik dan simulasi menggunakan software Patran/Nastran (Hartini, 2017).

Penulis berharap penelitian ini dapat memberi solusi produk alternatif tubing liner yang terjangkau dan memiliki kekuatan yang baik sebagai struktur pada unit sand control. Penelitian ini bertujuan untuk memperoleh nilai tegangan maksimum dan luluh material, menganalisis pengaruh penambahan lubang perforasi terhadap kekuatan material dan nilai konsentrasi tegangan yang dihasilkan.

\section{METODE PENELITIAN}

Penelitian ini diawali dengan pembuatan spesimen uji untuk pengujian tarik dan tekan. Pengujian tarik ini menggunakan spesimen uji dengan dimensi mengacu pada ASTM E8, 
sementara pada pengujian tekan mengacu pada ASTM E9. Pemodelan module part 3 dimensi dibuat menggunakan perangkat lunak Autodesk Inventor 2019 dengan ukuran dan geometri yang sesuai dengan spesimen uji. Setelah output file dari hasil pemodelan .ipt diperoleh, selanjutnya dilakukan simulasi finite element menggunakan perangkat lunak Abaqus 6.13. Hasil simulasi lalu dianalisis dan divalidasi dengan hasil eksperimen pada Tabel 1 dan 2. Langkah pengujian berikutnya yaitu melakukan simulasi kembali dengan memvariasikan ukuran diameter dan jumlah lubang perforasi pada tubing liner untuk dianalisis kembali hasilnya.

Tabel 1 Spesimen Bahan Uji Tarik

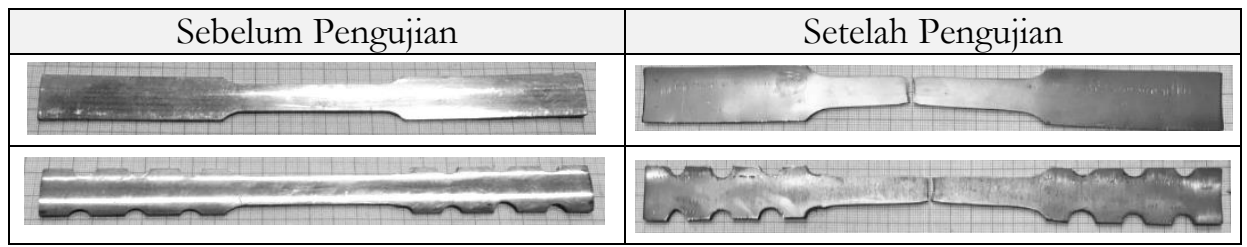

Tabel 2 Spesimen Bahan Uji Tekan

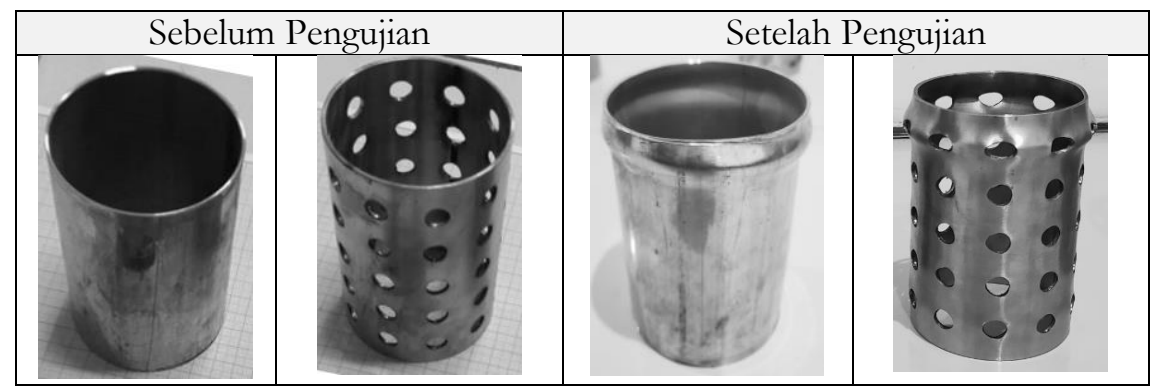

Bentuk lekukan-lekukan pada spesimen dikarenakan potongan melintang aksial pada spesimen dengan lubang perforasi Semakin besar ukuran diameter lubang maka akan menambah luas area perforasi pada tubing liner. Pada Tabel 3 adalah detil variasi dan ukuran spesimen yang dibuat.

Tabel 3 Variasi dan Ukuran Spesimen

\begin{tabular}{|c|l|c|c|c|c|c|c|}
\hline $\begin{array}{c}\text { Label } \\
\text { Spesime } \\
\mathrm{n}\end{array}$ & Keterangan & $\begin{array}{c}\text { Diameter } \\
\text { Lubang } \\
\text { Perforasi } \\
(\mathrm{mm})\end{array}$ & $\begin{array}{c}\text { Diameter } \\
\text { Luar Pipa } \\
(\mathrm{mm})\end{array}$ & $\begin{array}{c}\text { Jumlah } \\
\text { Lubang }\end{array}$ & $\begin{array}{c}\text { Luas } \\
\text { Area } \\
\text { Tube } \\
\left(\mathrm{mm}^{2}\right)\end{array}$ & $\begin{array}{c}\text { Luas Area } \\
\text { Perforasi } \\
\left(\mathrm{mm}^{2}\right)\end{array}$ & $\begin{array}{c}\text { Persen } \\
\text { Perforasi } \\
(\%)\end{array}$ \\
\hline TL_1A & $\begin{array}{l}\text { Spesimen tanpa } \\
\text { lubang perforasi }\end{array}$ & 0 & 76,56 & 0 & 28874,06 & 0 & 0 \\
\hline DL_1A & $\begin{array}{l}\text { Spesimen dengan } \\
\text { lubang 10 mm }\end{array}$ & 10 & 75,82 & 50 & 28594,97 & 3928,57 & 13,74 \\
\hline DL_1B & $\begin{array}{l}\text { Spesimen dengan } \\
\text { lubang 15 mm }\end{array}$ & 15 & 75,82 & 50 & 28594,97 & 8839,28 & 30,91 \\
\hline DL_1C & $\begin{array}{l}\text { Spesimen dengan } \\
\text { lubang 20 mm }\end{array}$ & 20 & 75,82 & 40 & 28594,97 & 12571,43 & 43,96 \\
\hline
\end{tabular}

Nilai konsentrasi tegangan Kt adalah perbandingan antara tegangan maksimum dengan tegangan nominal pada penampang spesimen (Palmiyanto, 2011). 

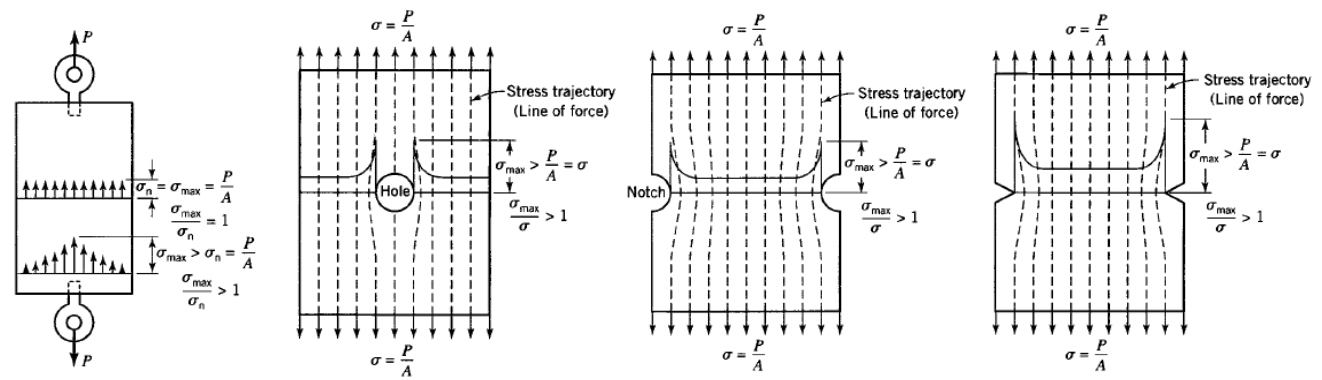

Gambar 1 Konsentrasi dan Arah Tegangan (Boresi, 2003)

Nilai konsentrasi ini tergantung pada orientasi retak dan geometri spesimen, sebagaimana ditunjukkan pada Gambar 1 di atas.

\subsection{Model Matematika}

Persamaan yang digunakan untuk menghitung nilai tegangan, regangan dan modulus elastisitas adalah sebagai berikut:

$$
\begin{aligned}
& \sigma=\frac{F}{A 0} \\
& \varepsilon=\frac{L-L 0}{L 0} \\
& E=\frac{\sigma}{\varepsilon}
\end{aligned}
$$

Dimana $\sigma=$ tegangan, $F=$ gaya tarik atau tekan, $A o=$ luas penampang awal, $\varepsilon=$ regangan, $E=$ modulus elastisitas, $L=$ panjang setelah ditarik, $L_{0}=$ panjang awal atau mula. Untuk nilai konsentrasi tegangan dapat dihitung dengan persamaan rumus berikut:

$$
K t=\frac{\sigma m}{\sigma o}
$$

Dengan $K_{t}=$ faktor konsentrasi tegangan, $\sigma_{m} \quad=$ tegangan maksimum dan $\sigma_{0}=$ Tegangan nominal.

\subsection{Pembuatan Part dan Pemodelan}

Proses meshing dilakukan menggunakan aplikasi mesh yang sudah termasuk dalam paket software Abaqus 6.13. Tipe mesh yang digunakan adalah mesh hexahedral dan tetrahedral seperti yang ditunjukkan pada gambar dibawah. Proses meshing sangat mempengaruhi hasil akhir dari suatu simulasi, sehingga grid independence test dilakukan untuk mendapatkan minimum jumlah node dan element agar dapat mengurangi beban komputasi dengan parameter input dan output secara berturut-turut adalah variasi ukuran mesh. Gambar 2 dan 3 menunjukkan hasil part meshing pada simulasi. 


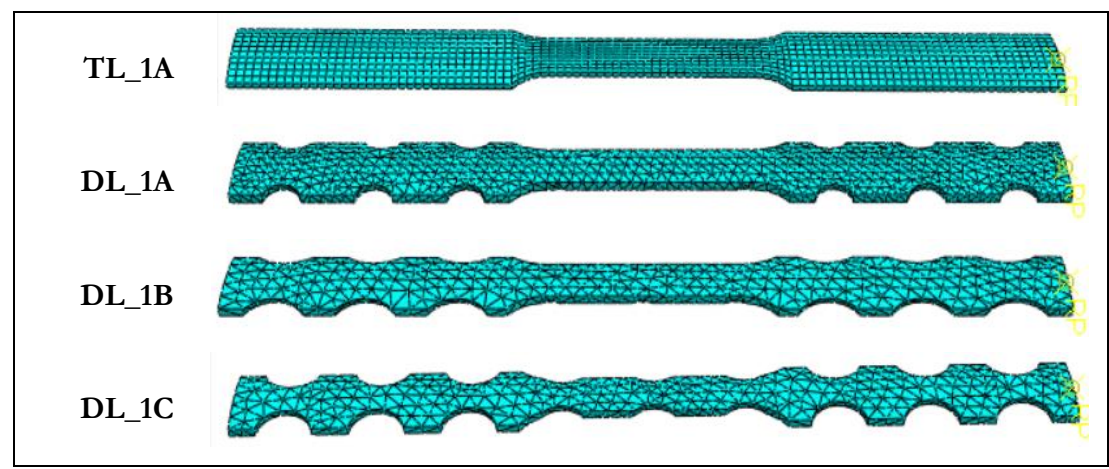

Gambar 2 Part Meshing Pada Spesimen Uji Tarik

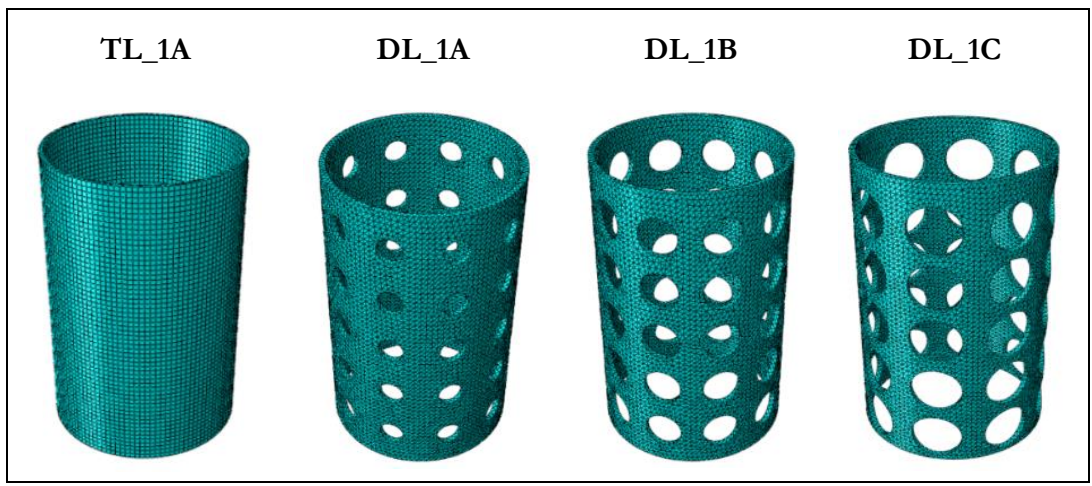

Gambar 3 Part Meshing Pada Spesimen Uji Tekan

\section{HASIL DAN PEMBAHASAN}

Pengujian dilakukan pada dua variasi spesimen tubing liner yaitu spesimen tanpa lubang perforasi dan dengan lubang perforasi berukuran $10 \mathrm{~mm}$. Data hasil pengujian di laboratorium, kemudian dihitung dengan persamaan di bawah. Pada uji tarik spesimen diberikan gaya tarik maksimum hingga putus atau break. Sementara untuk uji tekan diberikan gaya tekan maksimum hingga terjadi kondisi deformasi.

\subsection{Perhitungan Pada Uji Tarik dan Uji Tekan}

Dari data pengujian diperoleh nilai $F$ maksimum dan nilai panjang akhir L pada spesimen setelah pengujian. Kemudian dilakukan perhitungan untuk mendapatkan nilai besaran tegangan dan regangan, sebagaimana persamaan (1) dan (2) berikut ini:

$$
\begin{aligned}
\sigma \mathrm{TL}_{-} 1 \mathrm{~A} & =\frac{F}{A_{o}}=\frac{F}{W \times T} \\
\varepsilon_{\mathrm{TL}} L_{1 \mathrm{~A}} & =\frac{L-L_{o}}{L_{o}}=\frac{17,5 \mathrm{~mm}}{50 \mathrm{~mm}}=0,350=35,0 \% \\
& =\frac{11,79 \mathrm{kN}}{12,65 \mathrm{~mm} \times 1,56 \mathrm{~mm}}=597,45 \mathrm{MPa}
\end{aligned}
$$




$$
\begin{aligned}
\sigma D L_{-} 1 \mathrm{~A} & =\frac{F}{A_{o}}=\frac{F}{W \times T} \\
\varepsilon \mathrm{DL}_{1 \mathrm{~A}} & =\frac{L-L_{o}}{L_{o}}=\frac{21,3 \mathrm{~mm}}{50 \mathrm{~mm}}=0,426=42,6 \% \\
& =\frac{15,88 \mathrm{kN}}{12,72 \mathrm{~mm} \times 2,18 \mathrm{~mm}}=572,67 \mathrm{MPa}
\end{aligned}
$$

Dari nilai F maksimum yang diperoleh, maka perhitungan nilai tegangan untuk hasil uji tekan adalah sebagai berikut:

$$
\begin{aligned}
\sigma \mathrm{TL} \_1 \mathrm{~A} & =\frac{F}{A_{o}}=\frac{F}{\left(\frac{\pi}{4} d 1^{2}\right)-\left(\frac{\pi}{4} d 2^{2}\right)} \\
& =\frac{130,26 \mathrm{kN}}{185,6 \mathrm{~mm}^{2}}=701,83 \mathrm{MPa} \\
\sigma \mathrm{DL} \_1 \mathrm{~A} & =\frac{F}{A_{o}}=\frac{F}{\left(\frac{\pi}{4} d 1^{2}\right)-\left(\frac{\pi}{4} d 2^{2}\right)} \\
& =\frac{124,62 \mathrm{kN}}{255,77 \mathrm{~mm}^{2}}=487,23 \mathrm{MPa}
\end{aligned}
$$

\subsection{Simulasi Pada Pemodelan Variasi Uji Tarik}

Pada proses simulasi nilai modulus elastisitas atau young modulus dari hasil plot grafik kurva tegangan regangan eksperimen pada Gambar 4 dimasukkan pada sub menu module material. Berikut ini adalah perhitungan sesuai persamaan (3) untuk nilai modulus elastisitas. Hasil simulasi pada Gambar 5.

$E=\frac{\sigma}{\varepsilon}=\frac{364,3 \mathrm{MPa}}{0,0645}=5648 \mathrm{Mpa}$

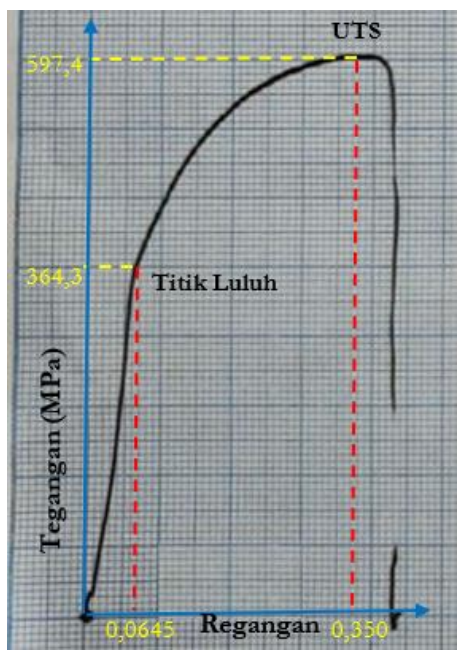

Gambar 4. Kurva Tegangan Regangan Uji Tarik 
A. Akhmadiansyah dan I. M. Miasa/ Journal of Mechanical Design and Testing 3(2), (2021), 68-82

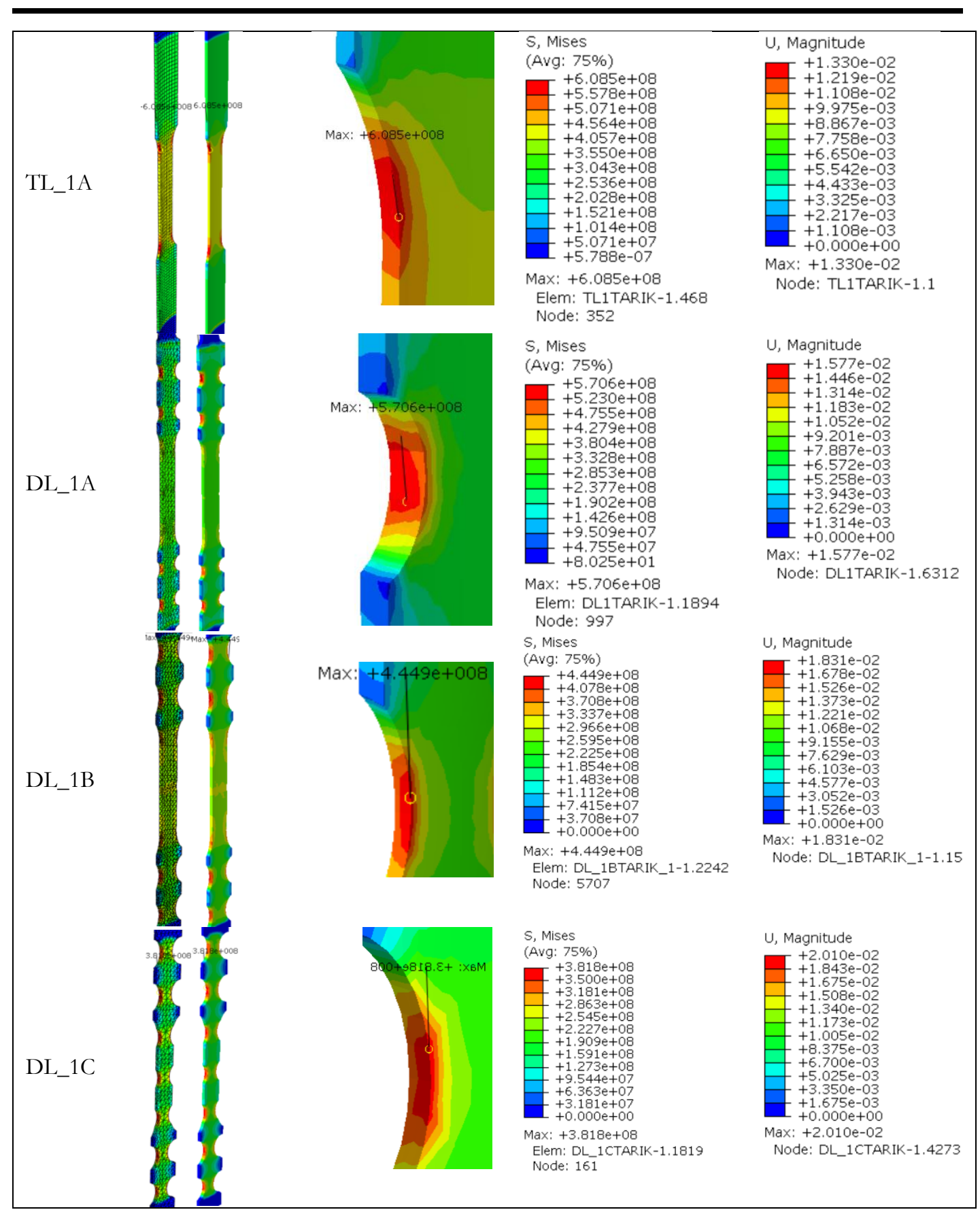

Gambar 5. Hasil Simulasi Variasi Uji Tarik

\subsection{Simulasi Pada Pemodelan Variasi Uji Tekan}

Perhitungan nilai modulus elastisitas, dari hasil plot grafik kurva tegangan regangan eksperimen pada Gambar 6 dimasukkan pada sub menu module material. Di bawah ini adalah perhitungan untuk nilai modulus elastisitas. Hasil simulasi pada Gambar 7. 
A. Akhmadiansyah dan I. M. Miasa/ Journal of Mechanical Design and Testing 3(2), (2021), 68-82

$$
E=\frac{\sigma}{\varepsilon}=\frac{350,91 \mathrm{MPa}}{0,0208}=16871 \mathrm{Mpa}
$$

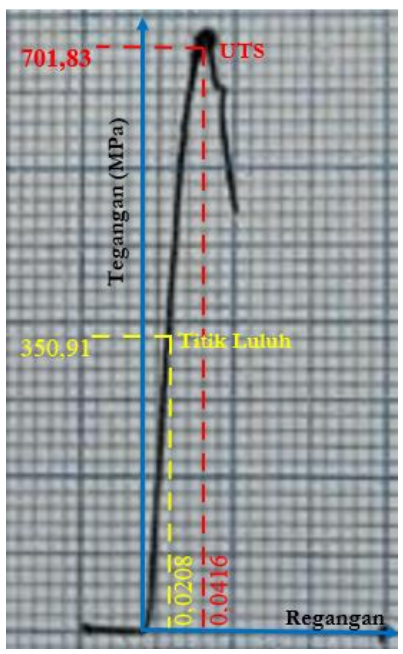

Gambar 6. Kurva Tegangan Regangan Uji Tekan

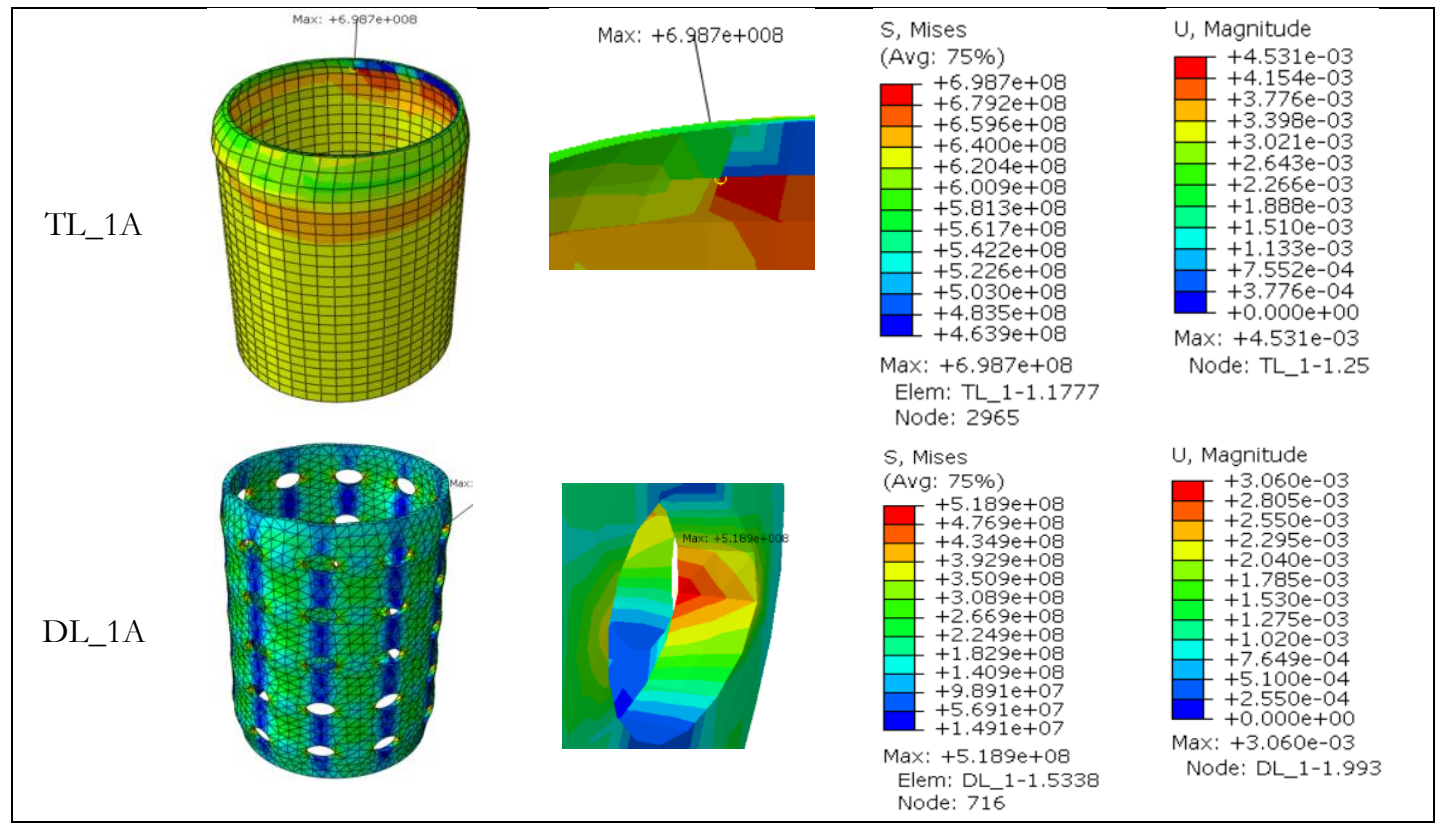


A. Akhmadiansyah dan I. M. Miasa/ Journal of Mechanical Design and Testing 3(2), (2021), 68-82

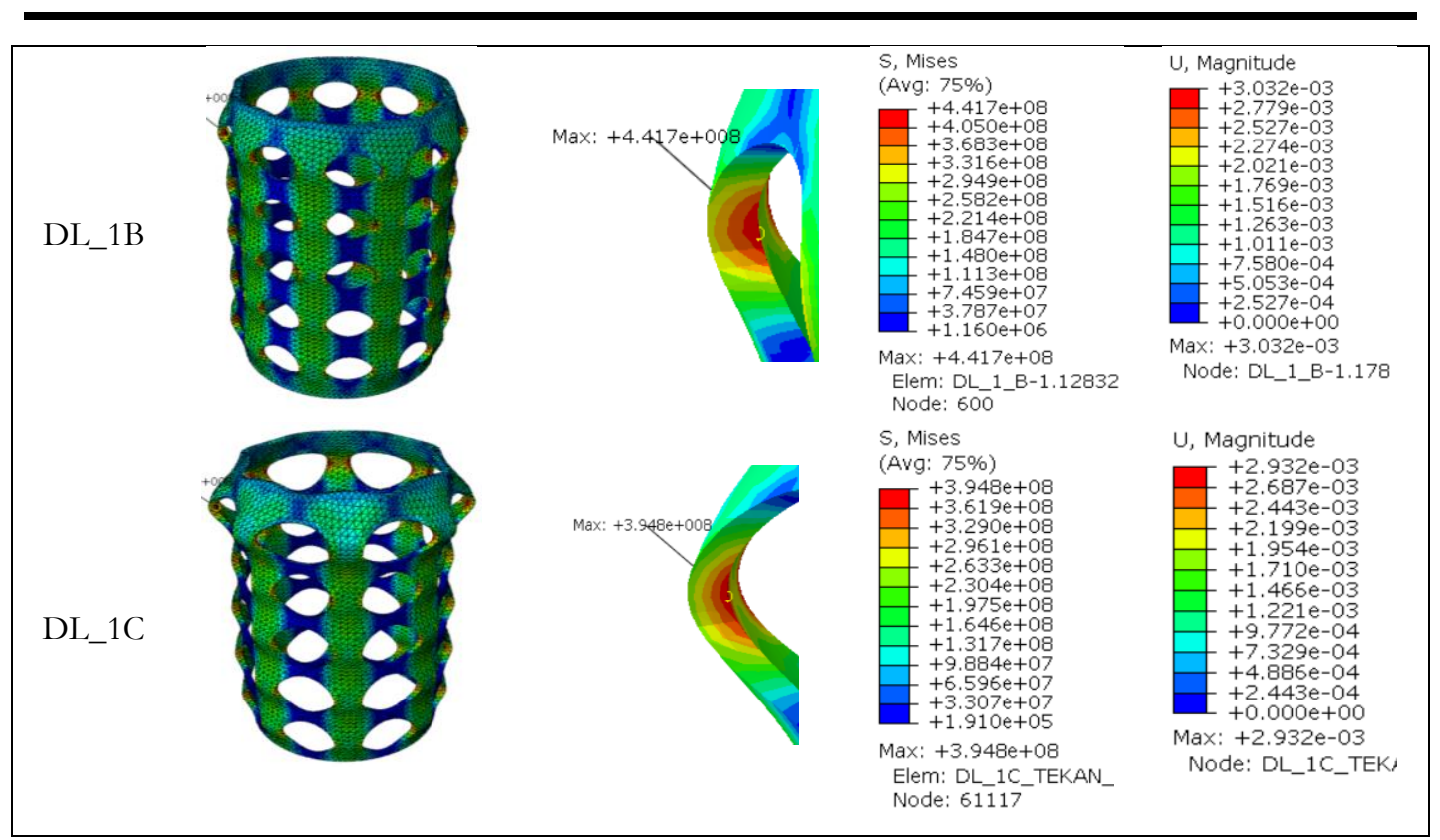

Gambar 7. Hasil Simulasi Variasi Uji Tekan

\subsection{Analisis Hasil}

Pada pengujian tarik, yang menjadi fokus perhatian adalah kemampuan maksimum spesimen dalam menahan beban atau gaya. Kemampuan ini umumnya disebut Ultimate Tensile Strength (UTS), atau tegangan tarik maksimum. Berdasarkan pengujian secara eksperimental maupun dengan pemodelan elemen hingga, diperoleh data-data sebagai berikut. Pada Tabel 4 dan Gambar 6, nilai tegangan mengalami penurunan seiring adanya penambahan lubang dan ukuran perforasi. Selisih atau error yang dihasilkan pada pengujian ini pada kisaran $0,36-1,85$ persen. Dapat dikatakan antara pengujian eksprimental dan simulasi keduanya memiliki hasil yang cukup valid.

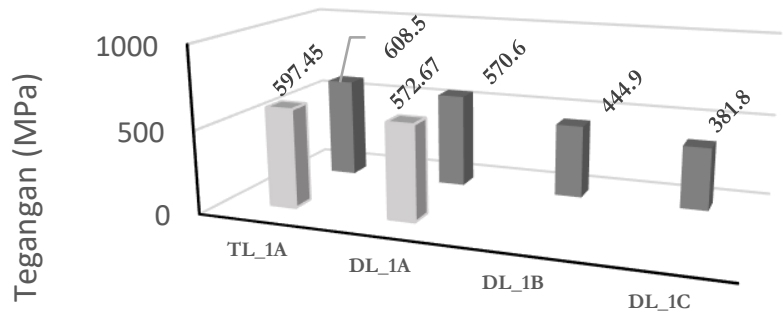

Uji Tarik $\quad$ Tarik, S Mises

Gambar 6 Grafik Tegangan Hasil Eksperimen dan Simulasi Tarik

Tabel 4 Nilai Tegangan Hasil Pengujian dan Simulasi Tarik

\begin{tabular}{|l|l|l|l|}
\hline No & Spesimen & Hasil Uji Tarik & Simulasi Tarik, S Mises \\
\hline
\end{tabular}


A. Akhmadiansyah dan I. M. Miasa/ Journal of Mechanical Design and Testing 3(2), (2021), 68-82

\begin{tabular}{|c|c|c|c|c|}
\hline & & Tegangan (MPa) & Tegangan (MPa) & Error $(\%)$ \\
\hline 1 & TL_1A (d=0 mm) & 597,45 & 608,5 & 1,85 \\
\hline 2 & DL_1A (d=10mm) & 572,67 & 570,6 & 0,36 \\
\hline 3 & DL_1B (d=15mm) & - & 444,9 & - \\
\hline 4 & DL_1C (d=20mm) & - & 381,8 & - \\
\hline
\end{tabular}

Pada eksperimen uji tekan maupun simulasi, spesimen diuji dalam bentuk geometri silinder utuh. Perbandingan hasil uji tekan dengan hasil simulasi memiliki nilai selisih yang kecil pada spesimen TL_1A sebesar 0,45\%. Sementara pada spesimen DL_1A terdapat selisih sebesar 6,5\% untuk nilai Stress Von Mises. Tabel 5 dan grafik untuk hasil uji tekan beserta simulasi seperti pada Gambar 7 berikut ini

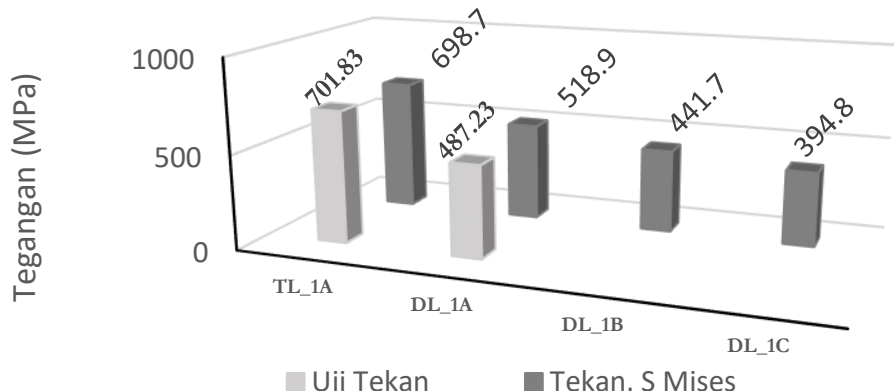

Gambar 7 Grafik Tegangan Hasil Eksperimen dan Simulasi Tekan

Tabel 5 Nilai Tegangan Hasil Pengujian dan Simulasi Tekan

\begin{tabular}{|c|c|c|c|c|}
\hline \multirow{2}{*}{ No } & \multirow{2}{*}{ Spesimen } & Hasil Uji Tekan & \multicolumn{2}{|c|}{ Simulasi Tekan, S Mises } \\
\cline { 3 - 5 } & & Tegangan $(\mathrm{MPa})$ & Tegangan $(\mathrm{MPa})$ & Error $(\%)$ \\
\hline 1 & TL_1A $(\mathrm{d}=0 \mathrm{~mm})$ & 701,83 & 698,7 & 0.45 \\
\hline 2 & DL_1A $(\mathrm{d}=10 \mathrm{~mm})$ & 487,23 & 518,9 & 6,50 \\
\hline 3 & DL_1B $(\mathrm{d}=15 \mathrm{~mm})$ & - & 441,7 & - \\
\hline 4 & DL_1C $(\mathrm{d}=20 \mathrm{~mm})$ & - & 394,8 & - \\
\hline
\end{tabular}

Pada pengujian eksperimental maupun pemodelan diperoleh nilai deformasi yang menunjukkan perubahan bentuk atau panjang dari suatu spesimen. Deformasi pada pengujian eksperimental dapat dideteksi lewat pengukur regangan (strain gange), grip length recorder atau dapat diukur secara manual marking. Sedangkan pada pemodelan elemen hingga, maka nilai deformasi dihasilkan dari proses kalkulasi menggunakan algoritma dan iterasi dalam perangkat lunak tersebut. Pada Tabel 6 berisi data nilai deformasi pada setiap pengujian. 
A. Akhmadiansyah dan I. M. Miasa/ Journal of Mechanical Design and Testing 3(2), (2021), 68-82

Tabel 6 Nilai Deformasi Hasil Eksperimen dan Simulasi

\begin{tabular}{|c|c|c|c|c|c|c|c|}
\hline \multirow{2}{*}{ No } & \multirow{2}{*}{ Spesimen } & $\begin{array}{c}\text { Hasil Uji } \\
\text { Tarik }\end{array}$ & \multicolumn{2}{|c|}{ Simulasi Tarik, U } & \multicolumn{2}{|c|}{$\begin{array}{c}\text { Hasil Uji } \\
\text { Tekan }\end{array}$} & \multicolumn{2}{|c|}{ Simulasi Tekan, U } \\
\cline { 3 - 8 } & $\begin{array}{c}\text { Nilai } \\
(\mathrm{mm})\end{array}$ & $\begin{array}{c}\text { Nilai } \\
(\mathrm{mm})\end{array}$ & Deviasi & $\begin{array}{c}\text { Nilai } \\
(\mathrm{mm})\end{array}$ & $\begin{array}{c}\text { Nilai } \\
(\mathrm{mm})\end{array}$ & Deviasi \\
\hline 1 & TL_1A (d=0mm) & 17,5 & 13,30 & $24 \%$ & 4,95 & 4,53 & $8,4 \%$ \\
\hline 2 & DL_1A (d=10mm) & 21,3 & 15,77 & $26 \%$ & 5,23 & 3,06 & $41 \%$ \\
\hline 3 & DL_1B (d=15mm) & - & 18,31 & - & - & 3,03 & - \\
\hline 4 & DL_1C $(\mathrm{d}=20 \mathrm{~mm})$ & - & 20,10 & - & - & 2,93 & - \\
\hline
\end{tabular}

Nilai deformasi pada hasil simulasi uji tarik bertambah seiring dengan penambahan ukuran diameter lubang perforasi dari 13,30 mm hingga 20,10 mm. Sedangkan pada hasil simulasi uji tekan perubahan nilai deformasi menurun pada kisaran 0,4-2 mm. Perbandingan nilai deformasi pada hasil pengujian dan simulasi dapat dilihat pada Gambar 8 di bawah ini.

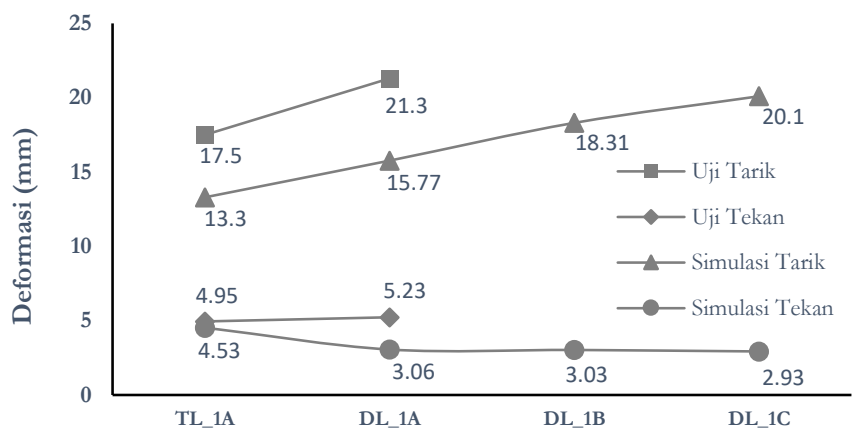

Gambar 8 Grafik Deformasi Hasil Eksperimen dan Simulasi

Deviasi atau error yang dihasilkan antara pengujian dengan simulasi pada beberapa variasi pemodelan, memiliki beberapa penyebab diantaranya:

1. Pembuatan ukuran lubang yang tidak akurat atau inkonsisten pada proses machining ditemukan hingga kisaran 0,5-1,5 mm (manual milling / drill). Sementara untuk desain pemodelan dengan perangkat lunak memiliki ukuran lubang yang sama dan konsisten.

2. Jarak antar lubang pada spesimen uji memiliki deviasi hingga kisaran 0,5 - 3,0 mm. Sedangkan pada pemodelan dengan perangkat lunak memiliki jarak yang sama.

3. Pada alat uji di laboratorium tidak terdapat mounting grip atau chuck yang dapat memfasilitasi pengujian tarik secara utuh dalam bentuk silinder. Geometri pada spesimen memiliki pengaruh dan hasil yang berbeda antara spesimen sesuai standar ASTM E8 dengan spesimen bentuk silinder.

\subsection{Analisis Faktor Konsentrasi Tegangan}

Faktor konsentrasi tegangan Kt sebagai akibat adanya penambahan lubang perforasi pada surface tubing atau pipa dapat dihitung dengan persamaan rumus (4). Nilai tegangan nominal atau tegangan rata-rata diperoleh dari distribusi tegangan yang ditunjukan oleh warna dominan 
pada contour interval spektrum warna deformed shape. Pada Tabel 7 berikut ini ditunjukkan nilai konsentrasi tegangan untuk setiap spesimen hasil simulasi.

Tabel 7 Nilai Konsentrasi Tegangan Hasil Simulasi

\begin{tabular}{|c|c|c|c|c|c|c|c|}
\hline \multirow{2}{*}{ No } & \multirow{2}{*}{ Spesimen } & \multicolumn{2}{|c|}{$\mathrm{K}_{\mathrm{t}}$, Simulasi Uji Tarik } & \multicolumn{3}{c|}{$\mathrm{K}_{\mathrm{t}}$, Simulasi Uji Tekan } \\
\cline { 3 - 8 } & & $\sigma_{\mathrm{m}}$ & $\sigma_{0}$ & $\mathrm{~K}_{\mathrm{t}}$ & $\sigma_{\mathrm{m}}$ & $\sigma_{0}$ & $\mathrm{~K}_{\mathrm{t}}$ \\
\cline { 3 - 8 } & & $(\mathrm{MPa})$ & $(\mathrm{MPa})$ & & $(\mathrm{MPa})$ & $(\mathrm{MPa})$ & \\
\hline 1 & TL_1A $(\mathrm{d}=0 \mathrm{~mm})$ & 608,5 & 405,7 & 1,499 & 698,7 & 620,4 & 1,126 \\
\hline 2 & DL_1A $(\mathrm{d}=10 \mathrm{~mm})$ & 570,6 & 332,8 & 1,714 & 518,9 & 308,9 & 1,679 \\
\hline 3 & DL_1B $(\mathrm{d}=15 \mathrm{~mm})$ & 444,9 & 222,5 & 1,999 & 441,7 & 221,4 & 1,995 \\
\hline 4 & DL_1C $(\mathrm{d}=20 \mathrm{~mm})$ & 381,8 & 159,1 & 2,399 & 394,8 & 164,6 & 2,398 \\
\hline
\end{tabular}

Pada hasil simulasi dapat dianalisis bahwa penambahan lubang di area surface berpengaruh pada meningkatnya nilai konsentrasi tegangan, seiring bertambahnya ukuran diameter dan jumlah lubang maka nilainya bertambah pula. Nilai Kt pada spesimen TL tanpa lubang secara berurutan sebesar 1,499 dan 1,126 pada hasil simulasi tarik dan tekan. Nilai ini bertambah menjadi 2,399 dan 2,398 pada spesimen DL_1C dengan diameter lubang dan luas area perforasi paling besar. Grafik pada Gambar 9 menunjukkan perubahan nilai konsentrasi tegangan $\mathrm{Kt}$ terhadap jenis spesimen yang disimulasi.

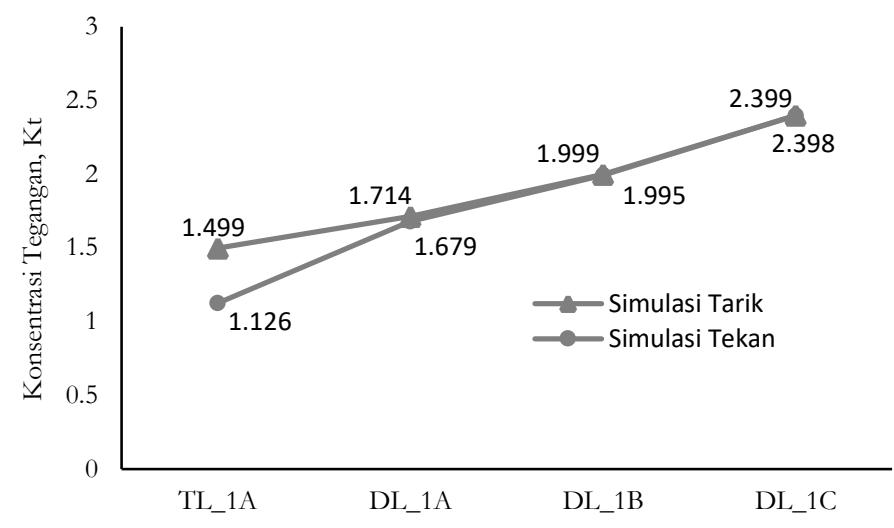

Gambar 9 Grafik Konsentrasi Tegangan Hasil Simulasi

Dengan meningkatnya nilai konsentrasi tegangan berdampak pada menurunnya nilai tegangan maksimum dan kekuatan material tubing liner, sebagaimana dapat dilihat pada Gambar 10 dan Gambar 11 berikut. 


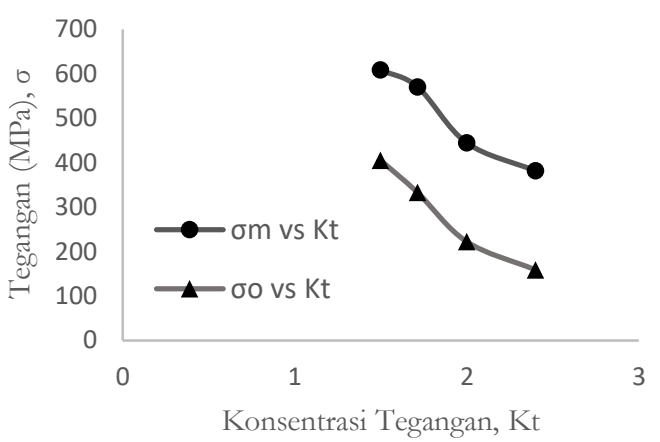

Gambar 10. Grafik Tegangan Terhadap Nilai Kt Pada Simulasi Uji Tarik

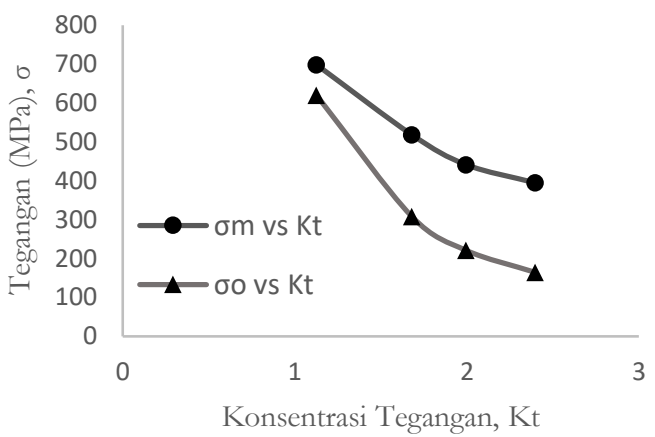

Gambar 11. Grafik Tegangan Terhadap Nilai Kt Pada Simulasi Uji Tekan

\section{KESIMPULAN}

Pengujian eksperimental pada material pipa tubing liner dengan penambahan lubang perforasi berdiameter $10 \mathrm{~mm}$ berpengaruh terhadap berkurangnya nilai $\sigma y$ sebesar $35 \%$ dari 364,3 MPa menjadi 234,27 MPa, nilai $\sigma \mathrm{m}$ uji tarik 4,15\% dari 597,45 Mpa menjadi 572,67 MPa dan nilai $\sigma \mathrm{m}$ uji tekan 30,6 \% dari 701,83 Mpa menjadi 487,23 MPa.

Validasi basis hasil eksperimen terhadap hasil simulasi uji tarik memiliki selisih atau error sebesar 0,36 \% untuk spesimen TL_1A dan 1,85 \% untuk spesimen DL_1A, maka dapat disimpulkan hasil validasi adalah baik $(<5 \%)$. Sementara validasi basis eksperimen terhadap hasil simulasi uji tekan memiliki nilai error yang kecil pada spesimen TL_1A sebesar 0,45 \%, sementara pada spesimen DL_1A terdapat selisih sebesar 6,5\%, maka dari itu hasil validasi dapat diterima atau accepted (5\%-10\%).

Penambahan perforasi secara aksial dengan variasi lubang berdiameter $10 \mathrm{~mm}, 15 \mathrm{~mm}$ dan $20 \mathrm{~mm}$ menyebabkan naiknya persen area perforasi dan terjadinya konsentrasi tegangan pada area sekitar lubang. Hal tersebut dapat meningkatkan nilai faktor konsentrasi tegangan (Kt) dari 1,12 hingga 2,39 dan menyebabkan nilai tegangan $V$ on Mises material semakin menurun. Pada simulasi uji tarik nilainya secara berurutan 608,5 MPa, 570,6 MPa, 444,9 $\mathrm{MPa}$ dan 381,8 MPa. Pada simulasi uji tekan nilainya adalah 698,7 MPa, 518,9 MPa, 441,7 MPa dan 398,4 MPa.

Penelitian ini masih memerlukan pengembangan lebih lanjut untuk mendapatkan datadata yang lebih lengkap. Penulis merekomendasikan untuk melakukan penelitian lebih lanjut, 
misalnya pengujian tarik dilakukan dalam bentuk geometri utuh dengan skala yang sesuai dengan kapasitas alat, proses pemesinan dalam pembuatan lubang dikerjakan menggunakan mesin milling otomatis atau semiotomatis dengan hasil yang lebih presisi dan pemodelan variasi bentuk serta susunan perforasi guna mendapatkan kemampuan filtrasi yang lebih efektif namun tetap memiliki kekuatan bahan sesuai standar.

\section{DAFTAR PUSTAKA}

Boresi, A. P., and Schmidt R. J., 2003, Advanced Mechanics of Materials, John Wiley \& Sons Inc., New York.

Dong, C., Gao, K., Dong, S., Shang, X., Wu, Y., Zhong, Y., 2017, A New Integrated Method for Comprehensive Performance of Mechanical Sand Control Screens Testing and Evaluation, Journal of Petroleum Science and Engineering, Volume 158, 775-783.

Dou, Y., Cao, Y., Li, M., Zhen, Y., 2019, Experimental and Theoretical Study on the Mechanical Characteristics of Perforated Casings, Procedia Structural Integrity, Volume 22, 33-42.

Hartini, D., 2017, Analisis Elemen Hingga untuk Faktor Konsentrasi Tegangan Pada Pelat Isotropik Berlubang dengan Pin-Loaded, Jurnal Ilmiah Bidang Teknologi, Volume 8(1), 69-78.

Mahmud, H.B., Leong, V.H., Lestariono, Y., 2020, Sand Production: A Smart Control Framework for Risk Mitigation, Journal of Petroleum, Volume 6(1), 1-13.

Palmiyanto, M. H., 2011, Perbandingan Hasil Analisa Konsentrasi Tegangan Pada Plat Berlubang Akibat Beban Tarik Dengan Menggunakan Metode Elemen Hingga dan Kajian Eksperimen, Jurnal Teknika ATW, Edisi 8, 26-33.

Penberthy, W. L., Shaughnessy, C. M., 1992, Sand Control SPE Series, Vol 1, Richardson, Texas.

Wang, W., Sheikh, Md., Hadi, M., 2014, Behaviour of perforated GFRP tubes under axial compression, Proceedings of the 7th International Conference on FRP Composites in Civil Engineering, Vancouver, 20-22 August.

Wang, Z., Lu, W., Hu J., 1994, Mechanism and Prevention of Casing Damage of Oil and Water Well in Oil Field, Petroleum Press, Beijing.

Wildhack S., Müssig S., Strahammer F., Leitner M., 2012, Sand Control with Ceramic Screens in Unconsolidated Reservoirs Demonstrated in The Mature Gaiselberg Oilfield, Oil Gas European Magazine, Volume 38, 74-78, http://www.oilgaspublisher.de/de/og.html.

Yang, R., Huang, Z., Li, G., Shi, H., Song, X., Shi, Y., 2018, An Integrated Workflow to Design Screen/ Slotted Liners in Geothermal Wells, Journal Geothermics, Volume 72, 277-287. 